\title{
Reformulation of knowledge: epistemological reading of Soviet Marxism in the post-Soviet times
}

\author{
Maria Chehonadskih ${ }^{1}$
}

Accepted: 9 March 2021 / Published online: 30 June 2021

(C) The Author(s) 2021

\begin{abstract}
The paper questions an official narrative of Soviet Marxism that had been formulated both by the Bolshevik leaders and the Western European Marxists. It proposes to shift the discussion from a historically constituted understanding of Soviet Marxism as a partisanship of theory to the epistemic conditions of Marxism after the October Revolution. The paper argues that a post-revolutionary Soviet logic assumes that theory should start where Marx ended and that it should act in a Marxist fashion across all conceptual and practical realms. Instead of asking 'how', the Soviet thought returns to the old pre-critical question of 'what is', and reformulates this 'what is' in the Marxist post-critical terms. Constructing a new critical concept of Soviet Marxism, the paper proceeds with the analysis of the post-critical status of knowledge after the revolution and recovers forgotten and repressed epistemological alternatives to orthodox Bolshevism.
\end{abstract}

Keywords Soviet and western Marxism · Geopolitics and epistemology · Reformulation of knowledge and revolution

\section{Introduction: geopolitics and Soviet Marxism}

Both before and after 1991, the dogmatic split into 'East' and 'West' has determined conceptualisations of Soviet Marxism. This dichotomy, as we shall see, emerged in the days of Lenin and the Communist International, when a new Soviet orthodoxy in Marxism was established as a canon in opposition to the bourgeois understanding of Marxism. The imaginary geographical areas of the East and the West referred in the nineteenth century to the enlightened and civilised European continent - the West, and to the wild and backward traditional Russian society-the East (Edie et al. 1965). In the Soviet period, the same dichotomy acquires a different ideological

Maria Chehonadskih

maria.chehonadskih@sant.ox.ac.uk

1 Max Hayward Visiting Fellow, Russian and Eurasian Studies Centre (RESC), St Antony's

College, University of Oxford, 62 Woodstock Road, Oxford OX2 6JF, UK 
subtext. In the critique developed by Lenin, 'West' signifies the geographical location of the party activist who is subject to criticism, and, because of this, geography could already be easily transformed into geopolitics. In other words, the 'West' produces 'bourgeois' capitalist theory if it does not follow the Soviet party line (Lenin 1966a). A somewhat different articulation appears on the other side of this dichotomy. The adjective 'Eastern' when joined to the noun 'Marxism' refers directly to a dark and savage barbarity, while the adjective 'Soviet' is a floating signifier that may embrace the 'barbaric' denotation of the word 'East' and could mean the State, which it produces, or may refer to the positive connotations associated with the October Revolution and its legacy. Although not fully free from the negative denotation, 'Soviet Marxism' is a still more neutral term, rather similar to the national categorisation of Marxism (Spanish Marxism or British Marxism). One negative formula, fully liberated from the ambiguity of nationalism or geopolitics, is diamat (dialectical materialism), while in the Soviet context the negative equivalent is simply 'bourgeois philosophy'. The doctrine of diamat, as opposed to istmat (historical materialism), has been formulated by Engels and further developed in Leninism and Stalinism. It applies dialectical theory to natural phenomena, thus arguing that nature develops according to the dialectical laws. The doctrine of historical materialism, as it appears in Marx, restricts itself to the study of society-an argument against diamat often repeated by the Western Marxists. However, Soviet Marxism does not reject istmat. It instead creates two respective branches of Marxism for the study of society and for the study of nature offering to Marxism its own philosophy of nature. Thus, the split into 'Eastern' and 'Western' Marxism according to the two types of materialisms corresponds to the schism between Marx and Engels, dialectics as a method of critique and dialectics as a metaphysical law, Marxism as critical theory and Marxism as ontology (Graham 1972; Lecourt 1977; Lukács 1971). At the same time, the theorists and philosophers who normally deviate from the canons of official Leninism and diamat often became known as representatives of "creative Marxism' (Levant and Oittinen 2014).

In these preliminary observations, we must return to the relevance of the concept of Soviet Marxism after 1991. As has already been mentioned, Soviet Marxism has both ideological (the category of East) and nationalist meanings (the Soviet State). After 1991, both disappeared and became part of the historical archive. An extremely negative attitude to this archive has led to all sorts of ideological manoeuvres when dealing with certain thinkers of the period. Thinkers either way different from the official doctrine, in fact there were many of this sort, have been depoliticised and removed from the communist tradition. These include, for example, the cultural-historical psychology of Vygotsky; the legacy of Proletkul't (Proletarian Cultural-Enlightenment Organisations) and Left Front of the Arts (LEF). ${ }^{1}$ Meanwhile, the inevitable clash with the communist and Marxist content in such works is normally waved away as elements of Stalinism within the text, or else as a forced

\footnotetext{
1 See the critique of cognitivist and anti-Marxist reading of Vygotsky in Veresov (2010). For a resent reassessment of Proletkul't, see White (2018, pp. 378-431). See also the critique of the Cold War narrative about constructivism and LEF in Buchloh (1986).
} 
Stalinist mimicry resulting from the attempt to pre-empt censorship. When what we call the communist content is too appealing, it serves as an archival remainder of the past that cannot be activated for today's purposes. It gives an impression that Soviet thought consists of exceptional personalities who were opposed to both Marxism and the Stalinist version of diamat. It also gives an impression that these singular authors exist outside of Soviet history and that the October Revolution did not create a consolidated body of thought. Therefore, the question is how to articulate this expanded claim on Marxism.

This paper will attempt to construct a critical concept of Soviet Marxism, which will allow to embrace both historically constructed categories of Soviet Marxism and the non-orthodox tendencies in the post-revolutionary theory that remain outside of this construction. The Soviet Marxism understood as this expanded field might help us to grasp the epistemic and conceptual constructions of the post-revolutionary situation. In our attempt to deal with the reception of Soviet Marxism, we use the categories 'Western', 'Eastern' and 'Soviet' Marxism in a historical, not critical, sense. We have to come to our own critical formulation of 'Soviet Marxism' after the consistent analysis of the corresponding historical narratives. The object of our study is the epistemic constructions of these categories as represented in the most symptomatic examples of the Western Marxist critique. Our reading may appear to be narrow and selective if we think of its aim only as a reconstruction of the intellectual history of Marxism across Western and Eastern borders. However, the actual aim is to unpack the representation of Soviet Marxism. Therefore, we are not going to consider the reception of Soviet Marxism or interpretations of Soviet history in recent studies. The main focus will be a counter-narrative to the official Western and Eastern Marxism, because they are connected in their attempt to discredit certain conceptions of Soviet Marxism.

\section{Marxism and the party}

There is a very well-known official narrative of Soviet Marxism in the Western Marxist tradition. It can be recovered in the key texts of Marxist thinkers and summarised in a few lines as dissatisfaction with the Engelsian line in philosophy and with Bolshevik political theory. It is official in both senses of the word: it looks at the development of Soviet Marxism through the development of the key Bolshevik leaders and ignores the party outsiders and non-party members. As a result, it coincides with the official discourse of the Soviet State, which Western Marxism meant to criticise. Accordingly, Bolshevik Marxism culminates in Stalinism and opens up a dark Medieval Age in Soviet history. Any retreat from this narrative seems to be presented as a deviating or dissident attitude. Perry Anderson's Considerations on Western Marxism is remarkable in this respect. It builds a predictable Trotskyist narrative of a great tradition of classical Bolshevism-Lenin, Bukharin, Trotsky, Preobrazhensky—which sharply declines and dies out under Stalinism:

The most advanced country in the world in the development of historical materialism, which had outdone all Europe by the variety and vigour of its theo- 
rists, was turned within a decade into a semi-literate backwater, formidable only by the weight of its censorship and the crudity of its propaganda. (Anderson 1989 , p. 20)

Thus, the only reason to contemplate Bolshevism is the mystery of the October aftermath. What was at stake in Western Marxism was to understand how Bolshevism was responsible or not responsible for Stalinism and to rethink the failure of the revolution to avoid the repetition of the same elsewhere.

There is nothing wrong in the ambition to understand Stalinism, but it seems to us that Western Marxism thought of itself as a lonely fighter and ignored similar concerns and reflections within the Soviet Union. Moreover, on the philosophical front, the critique of the Engelsian line, of the dialectics of nature and Lenin's theory of reflection led to the uncompromising division between 'West' and 'East'. This division was formulated by the Third International and supported by the communist parties across Europe (Korsch 2008b, pp. 138-139). That is probably why Henri Lefebvre interprets the doctrine of the dialectics of nature in the spirit of a conspiracy theory. He sees it as a tactical strategy that aimed to obscure real practical and theoretical questions. In the very moment of seizing power, Lefebvre contemplates, Stalin refocused attention away from what was at stake by plunging minds 'into the depths of Nature and cosmological speculation' (Lefebvre 2009, p. 3). Yet even before Stalinism, the international communist movement had a very particular construction and theoretical agenda. The party was an organic body of Marxism. It was understood as a linkage between theory and practice, intellectuals and masses. This justifies Perry Anderson's presentation of Marxism as a history of complicated relationships between the intellectuals and the party. Thus, a separation from the party, even if for a good reason, is tantamount to immediate isolation from the movement, and therefore, from practice (Anderson 1989, pp. 24-48). This perspective obscures the critique of Marxism within Marxism, but at the same time, it shows that the party was a central issue of Marxist identity. For instance, Merleau-Ponty treats Sartre's deviations from Marxism in terms of his position as a party outsider (1973, pp. 95-201), yet at the same time offers deep reflections about the party and Marxism when criticising Trotskyism. According to Merleau-Ponty, Trotsky was blind to the Thermidorian reaction in the mid-1920s precisely because of his uncritical perception of the party form. Trotsky could not grasp a contradiction between the party and the proletariat, between the 'socialist infrastructure' (collectivisation and planning) and the anti-socialist course of development, due to the fact that Marxism has never thought about these questions and fetishised the 'superstructures' of planning without seeing that they can belong to various political forms. To be able to see these contradictions, Trotsky would have had to go beyond the Marxism of that time and question the dialectical immanence of truth, which does not know the 'antinomies between proletariat and its party' or between 'economic and political forms' (Merleau-Ponty 1973, pp. 75-85). A naturalistic understanding of being and the idea of a successive historical development, writes Merleau-Ponty,

taught Trotsky that dialectic is buried in historical matter, that it can fail to develop if not taken up by the will of the most enlightened, that this will cannot, at each moment and in the immediate, coincide with the will of all the 
proletariat's factions, and that it is only after the event, when the dialectic is victorious, that the whole proletariat rallies to it and the revolution appears as a maturation; thus, provided that it be only temporarily, the dialectic can lose contact with the proletariat ... Finally, Trotsky learned that even if the Party is mistaken and degenerates, even if it is caught in the revolutionary ebb, the internal mechanism of permanent revolution can suddenly bring it back to itself. (Merleau-Ponty 1973, p. 87)

As a consequence, Trotsky was not able to reflect on his failures and continued to recreate Bolshevism (Merleau-Ponty 1973, p. 88). There is another consequence of Trotsky's case. It is thanks to the functioning of Marxism under the leadership of the Third International that anything beyond Lenin and party philosophers has been considered as a non-Marxist or ultra-leftist theory. Although Karl Korsch admits that the ideology of Lenin's materialism was a dictatorship that invaded Russia and covered all Western communist parties (Korsch 2008b, pp. 138-139), he remains Leninist in the sense of his restless attempt to understand Lenin's philosophy (Korsch 2008a, pp. 32-52; Korsch 2008b, pp. 117-143). It sounds even more paradoxical if we take into account his claim to differentiate Marxism from 'the system of intellectual oppression established in Russia' (Korsch 2008b, p. 143).

The position of Georg Lukács in the debates about dialectical materialism is particularly interesting, since he presents a geopolitical anomaly-a no-man's-land in the Western and Eastern Marxism divide. In the context of the 1920s, party-minded Marxism was, with a few exceptions, a philosophy of vulgar and mechanistic materialism. Lukács's extraordinary presentation of Marxist philosophy on the basis of Hegelianism and Neo-Kantianism in History and Class Consciousness (1923) echoed Korsch's attempt to bring philosophy back into Marxism. The paradox is that, however valued and influential in philosophical circles the book was, Lukács immediately received the reputation within these circles of being an idealist metaphysician and simultaneously was accused by the Comintern leaders and Soviet party philosophers of messianic utopianism, subjectivism and revisionism. ${ }^{2}$ The same controversy characterises The Young Hegel (1938). Conceived within the walls of the Moscow's Institute of Philosophy and realised during a period of active collaboration with Lukács's institute fellow and close friend Mikhail Lifshitz, it was defended as a doctorate thesis in the same institution in 1942 but was published in the USSR only in 1987. Thus, in the East, Lukács' émigré period was considered as a gradual, but insufficiently radical, correction of his past revisionist views, ${ }^{3}$ while in the West it was treated as a dramatic transition towards Stalinist conservatism.

\footnotetext{
2 The same objections Lukács raised himself in 1967, in the famous preface to History and Class Consciousness: (Lukács 1971, p. XVIII). About the influence on German philosophers, with a particular focus on Adorno, see Wiggerhaus (2007, pp. 66-81). About the development of Lukács's political views and the reception of his philosophy in international communist circles before and after the publication of History and Class Consciousness, see Löwy (1979, pp. 145-192).

3 Lukács's recently published investigative records from Lubianka prison give a sense of the ideological and political claims of the Stalinists in relation to Lukács (Sereda, Stikalin 2011).
} 
Paradoxically, Lukács was to some extent equally controversial for both the Eastern and the Western Marxist camps.

In the beginning of the essay 'What is Orthodox Marxism?' (1919), Lukács proposes a critical revision of what must be considered orthodoxy in Marxism. It is not a statement of faith that derives from Marx's work and articulates a dogmatic position; rather, it is the method that has to become a philosophical tenet (Lukács 1971, p. 1). The specific metaphysical inflection of Soviet debates about the essence of matter and form, or subject and object, must find a new epistemological resolution. Thus, Lukács follows the Western line of argument and 'denaturalises' materialism, attributing the question of matter exclusively to the understanding of social activity. The practical embodiment of dialectical materialism is to be found in the forcefully constructed 'bond between consciousness and action'. In other words, dialectical materialism as method is a force of becoming conscious in deed and act. Theory 'is essentially the intellectual expression of the revolutionary process itself ... theory does nothing but arrest and make conscious each necessary step, it becomes at the same time the necessary premise of the following one' (Lukács 1971, pp. 2-3). The ontologisation of the historical process and de-ontologisation of thinking and spirit leads towards anthropological interpretations of Hegel.

Lukács attributes to the 'contemplative' formal dialectics of Engels and to empiricism the characteristics of dualism since both separate method from being. Equally, Lenin represents voluntaristic and fatalistic views, because the 'obedience to laws' of nature excludes a historical understanding of social practice. The ideology of natural laws, in turn, corresponds to the logic of capitalist rationality. To present the process of rationalisation as a pure fact, calculability and quantitative measurement tends to abstract and reify social relations. The atomistic presentation of facts thereby creates partial systems that dialectics aims to penetrate and disenchant, by revealing the concrete totality (Lukács 1971, pp. 3-7). Orthodox Marxism, it is concluded, is a 'struggle against the insidious effects of bourgeois ideology on the thought of the proletariat' (Lukács 1971, p. 24).

The conclusions of 'What is Orthodox Marxism?' resonate with the statements of the Proletkul't movement. The struggle with ideology in Lukács corresponds to the prospect of de-alienation and, in Proletkultist programmes, to the socialisation of art and science (Bogdanov 1920). It explains why, while holding the post of Deputy People's Commissar for Education and Culture during the Hungarian Commune in 1919, Lukács implemented radical proletkultist ideas such as the proletarian theatre and programmes for sexual education (Löwy 1979, pp. 150-152). This agenda almost replicated the activities of Anatoly Lunacharsky's People's Commissariat for Enlightenment, which was grounded on Alexander Bogdanov's theory of proletarian culture (Fitzpatrick 1970). However, for Lukács the party remains a mediating link between the reified consciousness of the proletariat and a movement towards the correct understanding of its historical mission. The party directs the proletarian, and the proletariat directs the party (Lukács 1971, pp. 295-339). Bogdanov insisted on the autonomy of the proletariat from the party and believed that its culture could replace the bourgeois point of view only if the proletariat as a class develops its worldview independently. The concept of 'proletarian culture' means precisely the culture of the new industrial proletariat and collective labour, not the culture of 
professional revolutionaries and their party. This culture first has to overcome the relations of domination. In the bourgeois society, the ruler is as an active administrator of a passive and dependent labourer. According to Bogdanov, the intellectuals by definition reproduce such authoritarian relation of domination in the party. The dualism of leader and obedient masses represents precisely this. The unionisation of industrial production and the liberation of workers from the mechanical manual labour will gradually lead to a different type of social relation based on collectivism and comradeship. Proletarian culture is a struggle against authoritarianism in social relations, thinking and behaviour (Bogdanov 1920, pp. 33-42; Bogdanov 1990, pp. 438-450). However, Bogdanov suggests allying with the representatives of other classes who deeply share in the idea of a collectivist mode of life. The bourgeois classes may rise above their class and occupy a proletarian point of view. In this sense, proletarian culture embraces the progressive elements of all classes (Bogdanov 1920, pp. 24; Bogdanov 1990, pp. 360-376).

Although Lukács aimed to overcome Hegel through Marx, he operated within the logic of a simple reversal. The dialectical unity of the party and the proletariat is the same mystification of being that brought Trotsky to the reinvention of Bolshevism. Thought comes post festum in the costume of a party philosopher, to articulate the deed of a proletarian spirit. This was the main point of Lukács' self-critique (Lukács 1971, pp. XXII-XXIII), but it did not affect his understanding of the party form. Instead, he manages to incorporate reflection theory ${ }^{4}$ into The Young Hegel book, so as to prove the historical truth of Leninism (Lukács 1975, pp. XIV-XXX). To save the dialectical unity of the party and the proletariat, of the party and philosophy, Lukács sides with Lenin's programme of ontology for Marxism, which develops the 'Eastern' line of Marxist thought as opposed to bourgeois philosophy. However, this gesture of Lukács might equally be seen as a disturbance of this divide, especially if we have in mind the development of his doctrine of social ontology in 1960s. Lukács finds a compromise between an ontological claim to seek dialectical laws in nature and the attempt to displace the problem of ontology altogether in Western Marxism. He combines a focus on the historically determined forms of social practice with a broader question of what constitutes a relationship between nature and human nature, between organic and social forms. He rethinks this question through the Marxian and Hegelian understanding of labour, activity and practice (Lukács 1984, 1986). Lukács does not reject but synthesises research programmes across the Western and Eastern divide. The problem of nature and human nature brings ontology back into Marxism.

\footnotetext{
4 The main tenet of Leninist philosophy is that consciousness reflects being. Lenin's reflection theory establishes a relation of correspondence between representations and things (Lenin 1962, pp. 98-100; 232-238).
} 


\section{Soviet Marxism as Leniniana}

Party philosophy was identified with Soviet Marxism; therefore, the projects that developed outside Bolshevism have for a long time occupied the interest of specialists and scholars, but not the Marxists themselves. ${ }^{5}$ In the first half of the twentieth century Marxism was a territory of the Third International. Thus, to be a Marxist meant to have a membership card. The establishment of these rigid borders has to do with the appeal to Lenin's authority that is central to both Western and Soviet Marxism. Although we are not proposing to reject or forget Lenin, in our view there must be an objective analysis of what was called in the Soviet Union Leniniana-a genre and a name for the body of work in art and literature devoted to Lenin. Leniniana as knowledge production has to be treated in relation to its ideological limits.

The main authority here is Lenin's famous Materialism and Empirio-Criticism (1908), an attack on philosophical attempts to unite empiricism and Marxism in the Bolshevik circles. It is a paradox of Western Marxism that, despite the anti-dogmatic pathos, along with its critique of vulgar materialism, economism and diamat, it has managed to establish a statement of faith about Lenin's Empirio-Criticism. A chorus of Marxist voices attributed to this book the status of political wisdom. Thus, the discussion between the dissident Bolsheviks and Lenin about the philosophical foundations of Marxism has special importance for Korsch. For him, it provides an answer to the question of what constitutes philosophy for Marxism. Korsch sides with Lenin on the grounds of orthodoxy: any philosophy foreign to the classical Marxist tradition is non-Marxist, and it is due to the separation of Marxism from philosophy that 'it was not regarded as impossible ... for a leading Marxist theoretician to be a follower of Arthur Schopenhauer in his private philosophical life'. The anti-philosophical position of the Second International has led to the rejection of the philosophical content of Marxism and to the revision of a Marxist system supposedly lacking philosophical content (Korsch 2008a, pp. 33-34). Korsch's programme is to restore the philosophical roots of Marxism, which he locates in German idealism. This programme signifies a shift from the empirical positivism of the Second International to Hegelian philosophy and establishes a split between Western (Hegelian) and Eastern (empiricist) Marxism. According to Korsch, Marxism is not 'a transcendental Beyond' of German idealism, but a new form of knowledge linked to German idealism through the mediation of a new historical process of proletarian struggle (Korsch 2008a, p. 47). The relationship between social revolution and ideology is crucial since philosophy is an ideological problem and must be abolished simultaneously with the abolition of the bourgeois state and society (Korsch 2008a, p. 71-76).

However, the special status of Materialism and Empirio-Criticism primarily relates to 'the practical question'. Lenin's restoration of orthodoxy is a political, not

\footnotetext{
5 See, for example, the archive-based studies of Italian Slavists. An inclusive view of 'party Marxism' that extends to the populist parties, the so-called legal Marxists, the Socialist Revolutionary Party and all fractions of RSDRP is presented in a recent work of Daniela Steila (1996) and Guido Carpi (2016). See also Petrucciani (2015).
} 
a theoretical attempt to break with reactionary currents in Russian Marxism: 'Lenin decides philosophical questions only on the basis of non-philosophical considerations and results' (Korsch 2008b, p. 128). The standpoint of the party is the location from which Lenin's gesture can be understood. Nevertheless, Korsch admits that Lenin treats philosophy only in instrumentalist terms and that it leads him to the negation of philosophy before it realises its historical task. In other words, in his fight with empiricism, Lenin gives up on rigorous philosophical argument in the name of political urgency. He jumps ahead of philosophy so as to judge categories and problems of philosophy from the point of view of post-philosophy, as if it has already been accomplished. Consequently, the philosophical argument of the book appears naïve (Korsch 2008b, p. 128). ${ }^{6}$

For Korsch, Lenin's argument goes back to debates that philosophy has already overcome. Korsch obviously looks at the history of philosophy from the point of view of successive teleological developments. For him, any anachronistic shifts signify backwardness. As we have pointed out above, his view is similar to the Lukácsian one: Lenin returns to the separation of thought and being that characterises seventeenth- and eighteenth-century materialism and idealism (Korsch 2008b, p. 132). However, Korsch prizes the politicisation of philosophy, the return of a philosophical question in Lenin's book. Somewhat surprisingly, Korsch is ready to forgive Lenin's brutal philosophical argumentation, in spite of his own contention that in the Soviet Union Empirio-Criticism has turned into the official doctrine of vulgar materialism (Korsch 2008b, pp. 123-125).

The interpretation of Empirio-Criticism proposed by Althusser is even more paradoxical. For him, Empirio-Criticism demarcates the line between academic philosophers full of idealist fantasies and philosophy as theory, or, in other words, as a tactics for the critique of philosophical ideologies. Therefore, the vulgarity of Lenin's thesis is not important. As Lenin stresses himself, he had no intention to pretend to be a professional philosopher:

The real question is not whether Marx, Engels and Lenin are or are not real philosophers, whether their philosophical statements are formally irreproachable, whether they do or do not make foolish statements about Kant's 'thingin-itself', whether their materialism is or is not pre-critical, etc. For all these questions are and always have been posed inside a certain practice of philosophy. (Althusser 1971, p. 32)

\footnotetext{
${ }^{6}$ Korsch cites an extravagant passage from Lenin in which he deflates the argument about the experiential relationality of subject and object by claiming that in pre-historic times there was no subjective experience. Korsch admits that Lenin borrowed this argument from Plekhanov (Korsch 2008b, pp. 128129, f). Žižek, in his familiar anecdotal manner, remarks that it is precisely this realist naiveté that unites Lenin's argument with current trends in so-called speculative realism (Žižek 2012, p. 625). Lenin's chapter 'Did Nature Exist Prior to Man?' (Lenin 1962, pp. 75-86) does indeed echo Meillassoux's question: 'what is it that happened 4.56 billion years ago?' (Meillassoux 2008, p. 16). However, this leads Meillassoux to postulate a necessary contingent status of being, while Lenin suggests that being exists necessarily, precisely because it is fundamentally independent of the subject. An object that is nature exists prior to a subject, but this does not mean that the subject (and object) is contingent, as it exists within nature and is a part of its laws; therefore, the subject exists necessarily (Lenin 1962, pp. 75-86).
} 
Lenin proposes a fundamental distinction between science and philosophy. With regard to the striking method of Lenin's critique of empiricism by way of empiricism, Althusser has little to say, because Lenin's Philosophical Notebooks shows his return to dialectic and reveals his conception of 'scientific practice'. What matters is a new type of philosophising - a practical philosophising (Althusser 1971, p. 47-52). It is true that Lenin did his best to win the battle with empiricism. As a consequence, Marxism existed within the problematic of Leninism and militancy.

\section{The critical concept of Soviet Marxism: an epistemic approach}

The critique of Leniniana and the partisanship of theory corresponds to our intention to rethink Soviet Marxism from the perspective of its epistemological construction. What follows from this methodological decision is that, epistemically, Soviet Marxism cannot be seen separately from the event of revolution. De-centring this category from the discourse of the party, we return it to the historical place to which the very adjective 'Soviet' belongs - to the event of revolution. This minor step helps us to see that the revolution, which aimed to establish a communist society, treats any theoretical and practical effort as a Marxist effort, given that it is made in the context of a society struggling with the remnants of feudalism and capitalism and that a theorist shares the aims of the revolution. According to this logic, such effort could not be bourgeois or anti-Marxist. The motivation could only be criticised as anti-communist or anti-Marxist afterward, for example, in relation to disobeying the Leninist understanding of Marxism. Moreover, this approach allows us to abandon the divisive geopolitical and ideological construction of Eastern and Western Marxism.

The claim to reformulate knowledge in Marxist terms first appears in Alexander Bogdanov's writings on proletarian culture. If Copernicus looked at Earth from the point of view of the Sun, Bogdanov observes, Marx investigated society from the point of view of production and class struggle (Bogdanov 1990, pp. 366-367). The task of the working class is to complete this revolution and expand Marxian discovery to all fields of knowledge, including arts, natural and exact sciences (Bogdanov 1924a). Lenin made a similar claim by stating that Marxism 'assimilated and refashioned everything of value in the more than two thousand years of the development of human thought and culture' (Lenin 1966b, p. 317). However, if Bogdanov sees the task of refashioning as an open-ended process, which should be continued by the forthcoming generations of workers (Bogdanov 1924b, p. 120), Lenin treats it as an accomplished task. Proletariat has to learn from Marx, but it is not clear whether one can add anything else to the great doctrine (Lenin 1966b). The revolutionary rupture, thus pairs with an epistemological rupture of a particular kind: a post-revolutionary logic assumes that theory should start where Marx ended and that it should act in a Marxist fashion across all conceptual and practical realms.

Soviet Marxism is a reformulation of knowledge in Marxism terms. In a time of the post-revolutionary rapture with the capitalist mode of production, theory relates to the legacy of Marx in a specifically Soviet, post-critical sense. It does not continue the critique of political economy and capitalism, but instead relates itself to 
Marxism as a legacy and foundation for the post-capitalist history in which the critique of capitalism is irrelevant. This corresponds to the task of reworking all fields and realms of knowledge according to the results of the Marxian critical analysis. In this sense, Soviet Marxism presents a post-critical paradigm of thought that attempted to construct positive systems of knowledge for a socialist society. Lev Vygotsky claims:

It suffices to imagine Marx operating with the general principles and categories of dialectics, like quantity-quality, the triad, the universal connection, the knot [of contradictions], leap etc. - without the abstract and historical categories of value, class, commodity, capital, interest, production forces, basis, superstructure etc. - to see the whole monstrous absurdity of the assumption that it is possible to create any Marxist science while bypassing Das Kapital. Psychology is in need of its own Das Kapital - its own concepts of class, basis, value etc. - in which it might express, describe and study its object. (Vygotsky 1997, p. 257)

The cornerstone of Vygotsky's new Marxist discipline of 'general psychology' is a critical re-examination of various trends in the social sciences-reflexology, Gestalt psychology and psychoanalysis from the point of view of 'Capital'. Thus, the whole history of philosophy and theory is treated as construction materials, regardless of whether a chosen discourse was considered hostile to Marxism in Western political and academic circles.

For the psychologist Vygotsky, the question of what theory should do after capitalism was the question of how science might be reformulated in Marxist terms. The answer was that science has to question empirical facts by means of philosophy, while philosophy has to be placed in a historical context to overcome its metaphysical and idealist remnants. Vygotsky calls this double movement of philosophy towards facts and science towards philosophy 'experimental philosophy' and attributes this name to his own practice (Vygotsky 1999, p. 103). Thus, Marxist psychology for Vygotsky is the unity of method and practice (Vygotsky 1997, pp. 233-343). The task of method is to emend understanding and to transform social practice. Such an understanding of philosophy is not something specifically Soviet but is rather linked to the currents in philosophy and science that emerged at the beginning of the twentieth century. Referring to Bergson's study of memory and Cassirer's work on the psychology of speech, Vygotsky stresses a positive tendency to rely on experimental and clinical research in philosophy (Vygotsky 1999, p. 103).

Nevertheless, Vygotsky's aim of legitimating philosophy for Marxism may seem to share common ground with the Plekhanovite canon. For Plekhanov, the content of Marxism was not separated from the millennia-long history of 'philosophical materialism', which dates back to Democritus and culminates in the writings of Marx and Engels. Socialism is not only about economics; it is also a 'universal doctrine', or, equivalently, it is a philosophy that rests on the monist principles of the dialectical unity of subject and object, method and fact, thinking and being, and so on (Plekhanov 1976, pp. 129-134; Plekhanov 1977). In this respect, philosophy serves science as a method and a socialist 'world outlook' (Plekhanov 1976, p. 117). In fact, there is a triadic reciprocity between philosophy, socialism and science: the latter 
could arrive at the correct results, namely socialism, only if it followed the rules of the materialist method, because the materialist method was in itself grounded in socialist principles.

However, despite the great popularity of Plekhanov, many intellectuals questioned the name of philosophy in its relation to Marxism. Kautsky wrote: 'If you ask me ... whether Plekhanov correctly teaches Marxist philosophy, I will have to answer that Marx did not proclaim any philosophy, but proclaimed the end of any philosophy'. ${ }^{7}$ In the 1920s, Lenin and Lunacharsky thought that philosophy could be transformed into something else. It is remarkable that on the institutional level, in the Socialist Academy (the Communist Academy after 1924), as well as in the Communist University and the Institute of Red Professors, philosophy was expected to masquerade as this 'something else' - it was called the 'scientific worldview', or simply 'historical materialism' and 'dialectical materialism'. Moreover, in 1921 Lenin signed a document about the reorganisation of academia, excluding faculties of philosophy from universities. Philosophy gradually returned to the university departments only at the end of the 1920s (Kogan 2002). In this context, the "poverty of philosophy' meant the inability to serve a new socialist society, because it was a product of the old situation - of what existed before socialism, namely, slavery, feudalism and capitalism. The notorious philosophers' ships, which expelled religious thinkers to the capitalist West in 1922, signified, above all, a radical negation of philosophy due to its incurable reactionism. Thus, Vygotsky's experimental philosophy was another 'something else' in relation to philosophy, bringing together Plekhanov's philosophical materialism and the demand advanced by the radical left, that research should be concrete and that it should exist in the service of communist society.

This something else is what we conceptualise here as Soviet Marxism. The rejection of the reactionary past and reformulation of all existing knowledge in Marxist terms could mean either abolition of philosophy or subordination of this discipline to the tasks of revolution. The choice depends on how one understands the use of philosophy. Either way, abolition is almost impossible, because revolution unavoidably addresses philosophical questions. Kogan lists typical questions addressed to the Marxist lecturers at the public disputes in the early post-revolutionary years. They range from abstract philosophical subjects, such as 'What is matter?', 'How is an atom constructed?', 'Which comes first, action or need?' or 'Are Marxism and Materialism equivalent categories? If not, could Marxism exist without materialism?' to politically charged but nonetheless remarkably general questions, such as 'Whether it is possible to be a communist, without being a Marxist, and vice versa?' and 'You worship to and preach the idea of communism. Whether this idea is not the same God?' Even the question 'Is it true that Engels was a factory owner?' could be seen as an attempt to broach political topics (Kogan 2002, p. 115).

A similar tendency to phenomenological reduction can also be observed on a different level. Soviet Marxism thought of itself as a beginning of the new. Instead of asking how to criticise capitalist society, it questioned what society should do

\footnotetext{
$\overline{7}$ Quoted in Kogan (2002, p. 138).
} 
beyond capitalist history. Even though capitalism was not eliminated immediately after the revolution, and moreover, feudal forms shaped the construction of the Russian Empire, this logic of beyond determined theoretical commitments of Soviet Marxists. That is why in Soviet Marxism the only way to begin was to rely on old philosophical questions, which ought to find a new meaning. Instead of asking 'how' (to criticise, to approach, to understand), it returns to the old pre-critical question of 'what is' (matter, language, body, thinking) and reformulates this question in Marxist post-critical terms. That is why Vygotsky does nothing but answer what is body, what is thought, what is speech and what is emotions from the Marxist standpoint (Vygotsky 1997).

How to begin is famously also a Hegel question. For Hegel, philosophy cannot begin with 'something' that is mediated, it cannot rest on 'something' that conditions it, because that what conditions it is conditioned by something else, and so on to infinity. Hegel resists to begin with the empirical and conceptual pre-given; his beginning is an absolute beginning of the immediacy that cannot be further mediated. For immediacy establishes a self-determining move to concretion (Hegel 1977, pp. 1-41). For Soviet Marxism, such beginning is the axiom of Marx. It is this axiom that grounds the post-revolutionary being and cannot be further mediated. It is obvious that, according to Hegel, Marx is a relative, not an absolute beginning. This kind of relative beginning concerns not with our capacity to know but with our capacity to act.

To better understand this axiomatic status of Marx, let us evoke Jacques Lacan's meditation on Lenin's slogans 'Marx's theory is omnipotent because it is true'. Lacan says that this maximus pronounces that truth is an action that 'causes the whole effect' - the revolution and the transformation of society. As Soviet Marxism has it, according to Lacan, it is truth that acts and empowers, while knowledge, for instance, the science of Capital, 'does not necessarily lead to its utilization as a revolutionary power' (Lacan 2006, p. 738). Soviet Marxism concerns questions of how to transform life according to this truth. The beginning here is not Hegelian, but Socratic. It is precisely because it is the question of truth as action, writer Andrei Platonov was able to find 'communism in matter'. He located the truth of Marxist theory in the material particles of the universe. Platonov argued that communism could only arise from the 'poor' - the most equally distributed, cheapest and least limited element of nature-the power of light. If capitalism extracts surplus value from non-renewable resources (coal, gas, oil) and returns waste to the soil, the communist economy would harness the power of circulating 'atmospheric flows' (air, wind, light), thus abolishing the very idea of extraction and value. The agriculture and industry based on renewable energy sources would transform social relations in a village because of its communal form of governance and the equal distribution of resources. The achievement of 'communism in matter' requires the unity of ecological, social and political enquiries (Platonov 2004a, b).

The goal of our critical examination was a double-coded reception of Soviet Marxism. It has been revealed that membership of the official communist party is the driving force of demarcation between Marxist and non-Marxist theories. The party would be identical to the unity of theory and practice, the October Revolution and post-revolutionary Marxist theory. The contradiction between exercises 
in party critique and the necessity of remaining within the tradition is the unconscious of Western Marxism and the main cause of its reproduction of scholastic accounts of Soviet history, politics and theory, exemplified by what we called the genre of Leniniana. In a contemporary context, this contradiction replicates the rigid reproduction of dichotomies and divisions between 'Western' and 'Eastern' on the one hand, and, on the other, between 'Non-Soviet' within the Soviet and negatively Soviet-dissidents versus conformists, modernists versus Stalinists, or non-Marxists versus Marxists proper.

The focus on party and movement, capitalism and revolution represents a Western perspective, and one which was blind to the aftermath of the revolution. Our concerns are diametrically opposed to this agenda. The question is what comes after the revolution: what set of problems and decisions emerges out of the revolutionary experience? Merleau-Ponty correctly says that it is a mistake to think that a revolution will carry out an immanent negative movement until communism is established. The problem of permanent revolution is precisely that, according to Merleau-Ponty, it mystifies the restlessness of the revolutionary negativity that is the restlessness of work against counterrevolution. It is the fantasy of the party to think that positive affirmation is tantamount to the conservation of all unsolved problems. Quite the opposite is the case. Any actual revolution establishes an order and then abolishes itself in the new post-revolutionary positivity (Merleau-Ponty 1973, pp. 89-90). It is an idealist utopia to think that participation and enthusiasm are inexhaustible. The aftermath of revolution is what we discuss here in terms of the construction of Soviet Marxist epistemology. It articulates the unique historical and social experience of living and writing under and after the revolution.

The relevant question to pose to such an exposition would be as follows. Why still concern ourselves with Marxism if our constellation breaks with the accepted understanding of what Marxism is? If historically similar manoeuvres and gestures drove some intellectuals away from Marxism, why not abandon this notion altogether? Soviet Marxism as such could be treated as post-Marxism, because, as we have seen, it does not continue the critique of political economy and capitalism. Nevertheless, post-Marxism is taken to refer to the movement beyond traditional Marxism that occurred in France and Italy during the 1980s. The best solution seems to be to consider 'Soviet Marxism' as a name for a political project that had a beginning and an end, and as a particular epistemological construction that was related to the legacy of Marx in a specifically Soviet, post-critical sense. In Soviet Marxism, the pre-critical enquiry was taken from the standpoint of Marxist theory to result in a post-critical reformulation of knowledge in Marxist terms. In other words, retrospectively, our post-Soviet condition sanctions to construct such a critical concept of Soviet Marxism that is de-centred from the party, expanded to the logics of the Soviet experiment as such and correlative to the constitutive aim of October revolution to transit from capitalist to communist society. It is the concept for our postsocialist conjuncture.

Authors' contributions Not applicable. 
Funding Not applicable.

\section{Declarations}

Conflict of interest The corresponding author states that there is no conflict of interest.

Availability of data and material Not applicable.

Code availability Not applicable.

Open Access This article is licensed under a Creative Commons Attribution 4.0 International License, which permits use, sharing, adaptation, distribution and reproduction in any medium or format, as long as you give appropriate credit to the original author(s) and the source, provide a link to the Creative Commons licence, and indicate if changes were made. The images or other third party material in this article are included in the article's Creative Commons licence, unless indicated otherwise in a credit line to the material. If material is not included in the article's Creative Commons licence and your intended use is not permitted by statutory regulation or exceeds the permitted use, you will need to obtain permission directly from the copyright holder. To view a copy of this licence, visit http://creativecommons.org/licen ses/by/4.0/.

\section{References}

Althusser, L. (1971). Lenin and philosophy and other essays (B. Brewster, Trans.). New York, London: Monthly Review Press.

Anderson, P. (1989). Considerations on Western Marxism. New York, NY: Verso.

Bogdanov, A. (1920). Elementy proletarskoi kul'tury v razvitii rabochego klassa. Lektsii prochitannye $v$ Moskovskom proletkul'te vesnoi 1919 goda [The Elements of Proletarian Culture in the Development of Working Class. Lectures Delivered at Moscow Proletkult in Spring 1919]. Moscow: Gosudarstvennoe izdatel'stvo, Vserossiiskii Sovet Proletkul'ta.

Bogdanov, A. (1924a). O khudozhestvennom nasledstve' [On the Artistic Inheritance]. In O proletarskoi kul'ture (1904-1924) (pp. 142-157). Moscow: Kniga.

Bogdanov, A. (1924b). Proletariat i iskusstvo [The Proletariat and Art]. In O proletarskoi kul'ture (19041924) (pp. 117-124). Moscow: Kniga.

Bogdanov, A. (1990). Voprosy sotsializma: Raboty raznykh let [Writings on Socialism. Selected Essays]. Moscow: Politizdat.

Buchloh, B. H. D. (1986) Cold War constructivism, In S. Guilbaut (Ed.), Reconstructing modernism. Art in New York, Paris, and Montreal 1945-1964, (pp. 85-110). Cambridge, Massachusetts: MIT Press.

Carpi, G. (2016). Istoria Russkogo Marksizma [The History of Russian Marxism]. Moscow: Common Place.

Edie, J. M., Scanlan, J. P., \& Zeldin, M.-B. (Eds.). (1965). Russian philosophy: The beginnings of Russian philosophy. The Slavophiles, the Westernizers. Chicago: Quadrangle Books.

Fitzpatrick, S. (1970). The commissariat of enlightenment: Soviet education and the arts under Lunacharsky. October 1917-1921. Cambridge: Cambridge University Press.

Graham, L. (1972). Science and philosophy in the Soviet Union. New York: Knopf.

Hegel, G. W. F. (1977). Phenomenology of spirit (A.V. Miller, Trans.). Oxford: Oxford University Press.

Kogan, L. A. (2002). Na podstupakh k sovetskoi filosofii (pervye 'sverdlovtsy', 'sots. akademiki', 'ikapisty') [Approaches to Soviet Philosophy (The First Sverdlovskians, Socialist Academics, the Fellows of the Institute of Red Professors)], Voprosy filosofii, 5, 112-40.

Korsch, K. (2008a). Marxism and philosophy. In F. Halliday (Trans.), Marxism and philosophy (pp. 29-97). New York: Monthly Review Press.

Korsch K. (2008b). The present state of the problem of Marxism and philosophy-An anti-critique. In F. Halliday (Trans.), Marxism and philosophy (pp. 98-144). New York: Monthly Review Press. 
Lacan, J. (2006). Science and truth. In B. Fink, H. Fink, R. Grigg (Ed. and Trans.), Écrits (pp. 726-745). New York, London: W.W Norton \& Company.

Lecourt, D. (1977). Proletarian science? The case of Lysenko (B. Brewster, Trans.). London: NLB.

Lefebvre, H. (2009). Dialectical materialism (S. Kipfer, Trans.). Minneapolis, London: University of Minnesota Press.

Lenin, V. I. (1966a). Left-wing' communism-An infantile disorder. In J. Katzer (Trans.), Collected works, 45 vols, vol. 31: April-December 1920 (pp. 17-118). Moscow: Progress Publishers.

Lenin, V. I. (1966b). On proletarian culture. In J. Katzer (Trans.), Collected works, 45 vols, vol. 31 (pp. 316-317). Moscow: Progress Publishers.

Lenin, V., I. (1962). Materialism and empirio-criticism. Critical Comments on a reactionary philosophy. In A. Fineberg, C. Dutt (Trans. and Ed.), Collected works, 45 vols, vol. 14: 1908 (pp. 17-358). Moscow: Progress Publishers.

Levant, A., \& Oittinen, V. (Eds.). (2014). Evald Ilyenkov and creative Soviet Marxism. . Lienden, Boston: Brill.

Löwy, M. (1979). George Lukács-From Romanticism to Bolshevism (P. Camiller, Trans.). London: NLB.

Lukács, G. (1971). History and class consciousness. Studies in Marxist dialectics (R. Livingstone, Trans.). Massachusetts: The MIT Press.

Lukács, G. (1975). The young Hegel. Studies in the relation between dialectics and economics (R. Livingstone,Trans.). London: Merlin Press.

Lukács, G. (1984). Prolegomena. Zur Ontologie des gesellschaftlichen Seins 1. In Werke, 17 vols, vol. XIII. Neuwied am Rhein: Luchterhand.

Lukács, G. (1986). Prolegomena. Zur Ontologie des gesellschaftlichen Seins 2. In Werke, vol. XIV. Neuwied am Rhien: Luchterhand.

Meillassoux, Q. (2008). After finitude: An essay on the necessity of contingency (R. Brassier, Trans.). London: Continuum.

Merleau-Ponty, M. (1973). Adventures of the dialectic (J. Bien, Trans.). Evanston: Northwestern University Press.

Petrucciani, S., (Ed.,) (2015). Storia del Marxismo. I. Socialdemocrazia, revisionismo, rivoluzione (1848-1945). Roma: Carocci.

Platonov, A., P. (2004a). Elektrifikatsiia. Obshchie poniatiia [Electrification. Basic Definitions]. In Works, 3 vols, vol. I/2 (pp. 133-42). Moscow, IMLI RAN.

Platonov, A. P. (2004b). Svet i sotsializm [Light and Socialism]. In Works, 3 vols, vol. I/2 (pp. 218-220). Moscow, IMLI RAN.

Plekhanov, G. (1976). Fundamental problems of Marxism. In Selected philosophical works, 5 vols, vol. III (pp. 117-83). Moscow: Progress Publishers.

Plekhanov, G. (1977). The development of the Monist point of view of history. In A. Rothstein, A. Fineberg and R. Dixon (Trans.), Selected philosophical works, 5 vols, vol. I (pp. 486-703). Moscow: Progress Publishers.

Sereda, V., Stikalin, A., (Ed.), (2011). Besedy na Lybianke. Sledstvennoe delo Derdia Lukacha. Materialyk biografii [Lubianka Conversations. Investigative Records of Georg Lukács. Materials for the Biography]. Moscow: RAN, Institut Slavianovedeniia.

Steila, D. (1996). Scienza e rivoluzione. La recezione dell'empiriocriticismo nella cultura russa (18771910). Firenze: Le Lettere.

Veresov, N. (2010). Forgotten methodology. Vygotsky's Case. In A. Toomela, J. Valsiner (Ed.), Methodological thinking in psychology: 60 years gone astray? (pp. 267-95). Charlotte: Information Age Publishing.

Vygotsky, L. (1997). The historical meaning of the crisis in Psychology: A methodological investigation. In R. Van Der Veer, R. W. Rieber, J. Wollock (Trans.), The collected works of L. S. Vygotsky, 6 vols, vol. III (pp. 233-343). New York, London: Plenum Press.

Vygotsky, L. (1999). The teaching about emotions. Historical-psychological studies. In M. J. Hall, R. W. Rieber (Trans.), The collected works of L. S. Vygotsky, 6 vols, vol. VI (pp. 71-235). New York, London: Plenum Press.

White, D. J. (2018). Red Hamlet: The life and ideas of Alexander Bogdanov. Leiden, Boston: Brill.

Wiggerhaus, R. (2007). The Frankfurt School. Its history, theories and political significance (M. Robertson, Trans.). Cambridge: Polity Press.

Žižek, S. (2012). Less than nothing: Hegel and the shadow of dialectical materialism. London: Verso. 
Publisher's Note Springer Nature remains neutral with regard to jurisdictional claims in published maps and institutional affiliations. 